\title{
Chapter 5 \\ Unmanned Remotely Operated Search and Rescue Ships in the Canadian Arctic: Exploring the Opportunities, Risk Dimensions and Governance Implications
}

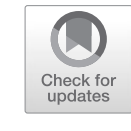

\author{
Jinho Yoo, Floris Goerlandt, and Aldo Chircop
}

\begin{abstract}
This chapter is a proactive risk exploration of hypothetical remotely operated search and rescue (SAR) ships in the Canadian Arctic. The harsh and remote environment in the region, combined with complicated coastlines and many uncharted or poorly charted traffic routes, makes it one of the most challenging SAR areas. Canada has committed itself to safety, environmental protection and sovereign presence in the area by maintaining joint SAR centres of federal government departments and mobilizing private volunteers. The characteristics of Canadian SAR response in the Arctic rest with its high dependency on heavy equipment such as aircraft, helicopters and icebreakers, entailing prolonged hours of response time. As recent climate change impacts and maritime traffic increase in the northern waters disclose safety gaps, innovation in SAR assets is anticipated. The safety gaps may be filled by state-of-the-art remote control technology. This chapter discusses remotely operated unmanned ships for SAR response, exploring their opportunities, risk dimensions and governance implications.
\end{abstract}

Keywords Canadian Arctic - Governance $\cdot$ Risk management $\cdot$ Risk prevention measures $\cdot$ Remotely operated search and rescue ships $\cdot$ Unmanned ships

\footnotetext{
J. Yoo $(\varangle) \cdot$ A. Chircop

Marine \& Environmental Law Institute, Schulich School of Law, Dalhousie University,

Halifax, Canada

e-mail: jn997722@dal.ca; aldo.chircop@dal.ca

F. Goerlandt

Department of Industrial Engineering, Dalhousie University, Halifax, NS, Canada

e-mail: floris.goerlandt@dal.ca
} 


\subsection{Introduction}

Could we imagine a ship remotely controlled from a distance of $8000 \mathrm{~km}$ ? This long-distance test has been successfully passed, and a vessel-borne sensor with machine learning has advanced to identify the brand name of beer cans in the water (Wärtsilä 2017; Baraniuk 2017). The Yara Birkeland, an 80 m-long autonomous cargo ship, is expected to be in service within a few years (Baraniuk 2017). Notably in May 2019, the first-ever remotely controlled cargo ship completed a 22 h-long voyage between the United Kingdom and Belgium with a maximum payload capacity of 2.5 tonnes (Amos 2019).

Drones have been tested in the Canadian Arctic for safety monitoring since the first remote trial at Alma, Quebec, in June 2017 (Transport Canada 2018). One Australian drone successfully searched and rescued persons at sea by dropping an inflatable life raft (Haddou-Riffi 2018). In line with these technical innovations, in May 2018, the International Maritime Organization (IMO) coined a new term, maritime autonomous surface ships (MASS), to describe these new technologies. MASS were categorized into four stages: (1) manual operation with automated processes and decision support, (2) manned remotely controlled ships, (3) unmanned remotely controlled ships and (4) fully autonomous ships (IMO 2018a).

Given the limitations of the present SAR response time (Chase 2013) and the safety risks to SAR responders in the Arctic, the authors anticipate the third stage of unmanned remotely controlled ships to be able to play a potential role as a breakthrough in SAR response. In particular, in parallel with the recent improvements of multitier communication systems, unmanned and remotely operated SAR ships (RO-SARS) could open a new phase of SAR operations, assisted by a tailored design for rescue operation in the Canadian Arctic. Considering wind, current and wave height effects, a preliminary conceptual design can feature a high-speed craft (HSC) of $24 \mathrm{~m}$ or more with a capacity of at least 12 passengers.

However, despite the probable benefits, unmanned RO-SARS would also face novel risks, raising safety concerns to various stakeholders (Aven and Renn 2010). This chapter aims at exploring the opportunities, risk dimensions and governance implications of unmanned RO-SARS in the Canadian Arctic context from the sociotechnical and legal perspectives. The discussion is guided by two research questions. First, given the Canadian northern SAR context, what opportunities and risk dimensions are anticipated if and when unmanned RO-SARS are deployed? Second, what governance implications and risk prevention measures can be drawn, considering preliminary risk assessment of RO-SARS under the International Risk Governance Council (IRGC) framework? The outcome of this exploratory analysis will likely contribute to developing a conceptual design, risk characterization and regulatory model of RO-SARS in later research. 


\subsection{SAR in the Canadian Arctic Context}

The International Convention on Maritime Search and Rescue, 1979 (SAR Convention), defines "search" as "an operation ... to locate persons in distress" and "rescue" as "an operation to retrieve persons in distress, provide for their initial medical or other needs, and deliver them to a place of safety" (SAR Convention 1979, Annex, chap 1). These definitions are overarching principles in designing, manufacturing and operating RO-SARS.

\subsubsection{Navigational Complexity and Uncertainty in the Canadian Arctic}

The Canadian Arctic, and in particular the Northwest Passage (NWP), which extends $1450 \mathrm{~km}$, is a uniquely complex navigational area consisting of multiple routes as shown in Fig. 5.1. Its characteristics include a combination of (1) a huge geographical area accounting for $40 \%$ of Canada's land mass (Esri n.d.); (2) an extensive and complicated coastline with landfast ice in many areas; (3) an estimated 50,000 giant icebergs as well as drifting ice accompanied by strong winds,

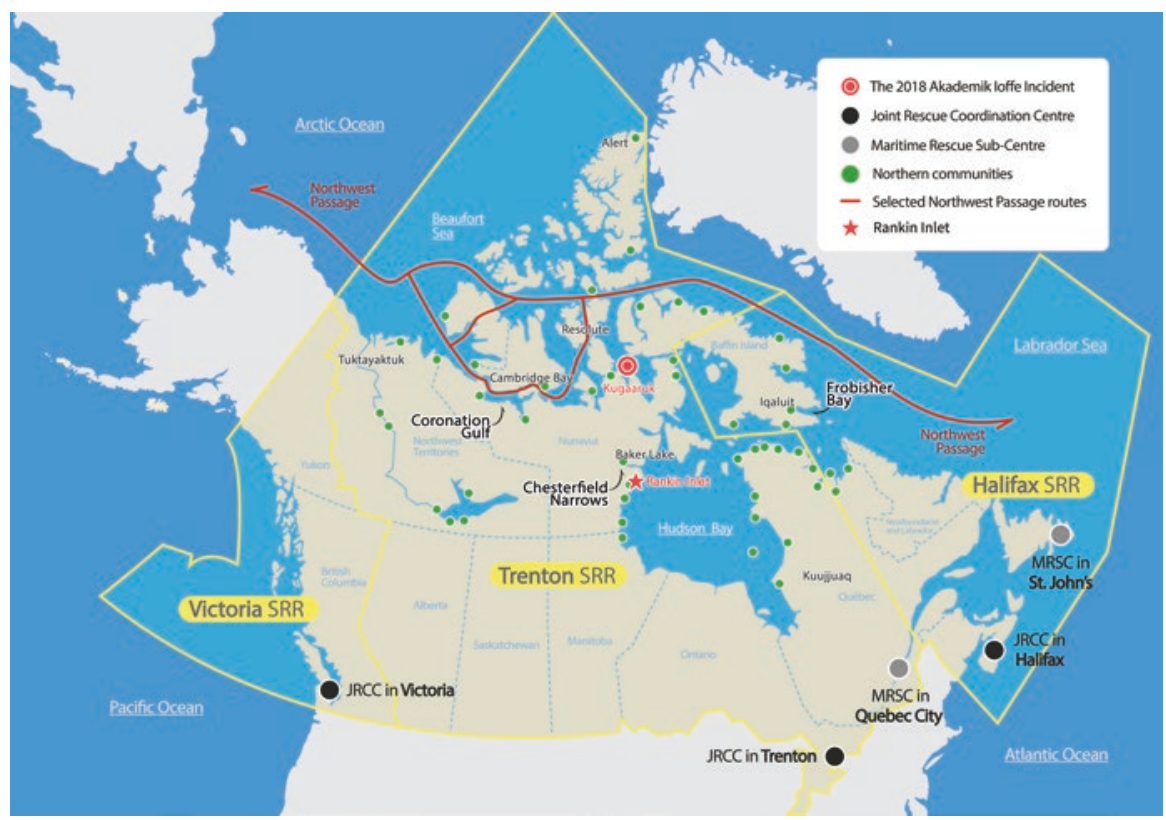

Fig. 5.1 SAR centres in the Canadian Arctic and the 2018 Akademik Ioffe incident (Office of the Auditor General of Canada 2013, 2014) 
spray, fog and waves (Esri n.d.; Arctic Council 2009); (4) complicated sea routes through an archipelago consisting of over 90 major and 36,400 minor islands (World Atlas 2018); (5) the fact that only 10 per cent of the routes are considered adequately charted, although in some areas this figure has improved through recent surveys (Struzik 2018); (6) a complete lack of ports with any significant infrastructure; and (7) scarce emergency infrastructure for fuel, spare resources and trained personnel.

Most importantly, the Canadian Arctic is not only fundamental to Canada's national identity but is the homeland of Indigenous peoples across the Yukon, the Northwest Territories and Nunavut. Canada has maritime boundary disputes and incomplete boundaries with the United States in the Beaufort Sea and Denmark in the Lincoln Sea (Government of Canada 2010). Most significantly, under international law, Canada claims a historic title to the waters of the Canadian Arctic archipelago over which it exercises sovereignty (Chircop et al. 2018). Shipping in the archipelagic waters and the territorial sea and the exclusive economic zone seaward of the straight baselines enclosing the archipelago is governed by stringent national law, most especially the Arctic Waters Pollution Prevention Act, 1970 (AWPPA), its regulations and the regulations under the Canada Shipping Act, 2001 (Fisheries and Oceans Canada 2009; Chircop et al. 2018).

\subsubsection{Multilevel Canadian SAR Resources in the Context of Increasing Demand}

Canadian Arctic SAR is based on shared responsibilities of federal, territorial and municipal governments, as well as Indigenous communities, volunteers and commercial sectors (Senate of Canada 2018). SAR response entails reliance on heavy equipment, such as the dedicated 35 SAR aircraft (e.g., 17 fixed-wing and 18 rotary) operated by the Royal Canadian Air Force (2018), the 23 helicopters operated by the Canadian Coast Guard (2016) and the 15 icebreakers of the Canadian Coast Guard (2019) (Fisheries and Oceans Canada 2009; Senate of Canada 2018; Canadian Coast Guard 2019). These resources are mostly deployed in the three Joint Rescue Coordination Centres (JRCCs) and two Maritime Rescue Sub-Centres run by Canada's Department of National Defence and the Canadian Coast Guard (CCG) (part of Fisheries and Oceans Canada) (Fig. 5.1). Volunteer SAR organizations include the Canadian Coast Guard Auxiliary with about 4000 volunteers and 1100 vessels across 16 bases in the Arctic; the Civil Air Search and Rescue Association (CASARA); and the Search and Rescue Volunteer Association of Canada (SARVAC) (Office of the Auditor General of Canada 2013). Commercial vessel operators, such as Fednav and Groupe Desgagnés, have also provided assistance. 
Although these SAR resources appear to be considerable, the increased SAR demands in the northern region are presumed to exceed existing capabilities. The SAR resources are expected to cover both land and sea areas. Covering 18 million $\mathrm{km}^{2}$ of land and water, in 2017 the three JRCCs responded to about 10,000 air, marine and humanitarian incidents. Each JRCC addresses approximately 3000 incidents every year (Senate of Canada 2018; Office of the Auditor General of Canada 2013). Over 500 SAR missions were completed in the Canadian Arctic for the last 5 years immediately preceding 2019, compared with the yearly average of 29.3 accidents and incidents in the entire Arctic between 1995 and 2004 (Ward 2019; Arctic Council 2009).

In 2018, a CCG Arctic base was established in Rankin Inlet as part of Canada's Arctic strategy to involve 14 northern Indigenous communities in SAR operations (Government of Canada 2009; Crown-Indigenous Relations and Northern Affairs Canada 2019). The Rankin Inlet Inshore Rescue Boat station in Nunavut will provide maritime SAR support during the summer season and will be crewed by Indigenous peoples trained by the Canadian Coast Guard (Canadian Coast Guard 2019).

\subsection{Opportunities of RO-SARS}

\subsubsection{Increasing Vessel Traffic and Precursors of Arctic Accidents}

The number of ship voyages to the Canadian Arctic increased from 123 in the year 2005 to 347 in 2016, including 147 voyages for cargo ships, 131 fishing vessels and 20 cruise/passenger ships (Lasserre 2018). Furthermore, there were 6036 cruise passengers in 2016, compared with 1239 in 2005 (Lasserre 2018). In 2017 alone, 178 vessels made about 400 visits to the Arctic including 32 transits through the NWP (LeBlanc 2018a).

Although there have not been massive fatalities in Northern Canada since the 1990s, some incidents could serve as precursors of disasters in the near future, such as the Hanseatic which ran aground with 149 passengers on board in 1996, the Clipper Adventurer which hit underwater ledges with 128 passengers in 2010 (TSBC 2012) and the Akademik Ioffe with 126 passengers, which was grounded in 2018 (Fig. 5.1) (TSBC 2019). It is plausible to assume that in case of more traffic entering the Arctic, the number of incidents will also increase. The year 2017 saw 71 marine incidents in the entire Arctic, up 29\% year-on-year, with 29 total losses in the Russian Arctic and Bering Sea between 2008 and 2017 (Allianz 2018). Accordingly, it is reasonable to prepare for machinery damage and failure when navigating the Canadian Arctic, the conventional biggest cause of incidents in the region (Arctic Council 2009). 


\subsubsection{Limitations of the Canadian Arctic SAR Response}

Regardless of multilevel SAR resources, geographical remoteness and a complete lack of ports have created inherent limitations to the response time in the Canadian Arctic in the sense that how fast a response can be made depends on how close assets are located (Struzik 2018). Most importantly, the fact that all the JRCCs are located at the far south of the country (Fig. 5.1) has caused the average response time to be about $10 \mathrm{~h}$ under average ice conditions during the navigation season (Dalaklis 2019). In the Akademik Ioffe incident in 2018, the SAR flight took $9 \mathrm{~h}$ from the JRCC in Trenton, Ontario, to the grounding site (Fig. 5.1) (TSBC 2019; Struzik 2018). Similarly, SAR ships could take days to arrive at a site and rescue people (e.g., Hanseatic incident) due to the vast area and because the average speed of vessels on Arctic routes is known to be around 7 to 13 knots, compared with 21 to 25 knots in open sea (Plass et al. 2015). The number of people who can be delivered by helicopter is also extremely limited and helicopters need frequent refuelling stops.

Safety gaps and emerging risks have been mentioned at the federal level because of multifarious challenges: (1) the limited hydrographic survey and nautical charting of marine routes, (2) "dead zones" of radio communications, (3) the lack of trained SAR personnel, (4) ageing equipment, (5) insufficient icebreaking services, (6) the lack of land base connectivity through fibre optics, (7) the low bandwidth of satellite communications and (8) prolonged SAR time (Office of the Auditor General of Canada 2013, 2014; LeBlanc 2018a, b; Brown 2018). Given the financial burden of SAR amounting to over CAD 136.9 million (Canadian Coast Guard 2018), adding more aircraft, helicopters and icebreakers will not be a continuous and sustainable answer. Technical innovation in SAR is required.

\subsubsection{The Changing SAR Technology: Remote Control and Unmanned RO-SARS}

\subsubsection{Communication Links Under Innovative Improvement}

There have been multitier and hybrid approaches to improving marine communication technologies. Figure 5.2 provides a visual impression of some of these technologies: low earth orbit satellite services by 2022 (LeBlanc 2018b); Enhanced Satellite Communication Project, Polar (ESCP-P) (National Defence 2019); nano satellite and microsatellites called the "Gray Jay Pathfinder" (University of Toronto 2019; Boucher 2019; Cho 2019); and terrestrial systems by fibre-optic cables extending to the northern areas (Nuvitik Communications 2018). These developments are believed to gradually contribute to paving innovative foundations for effective SAR communication and response. For example, in May 2019, Canada 


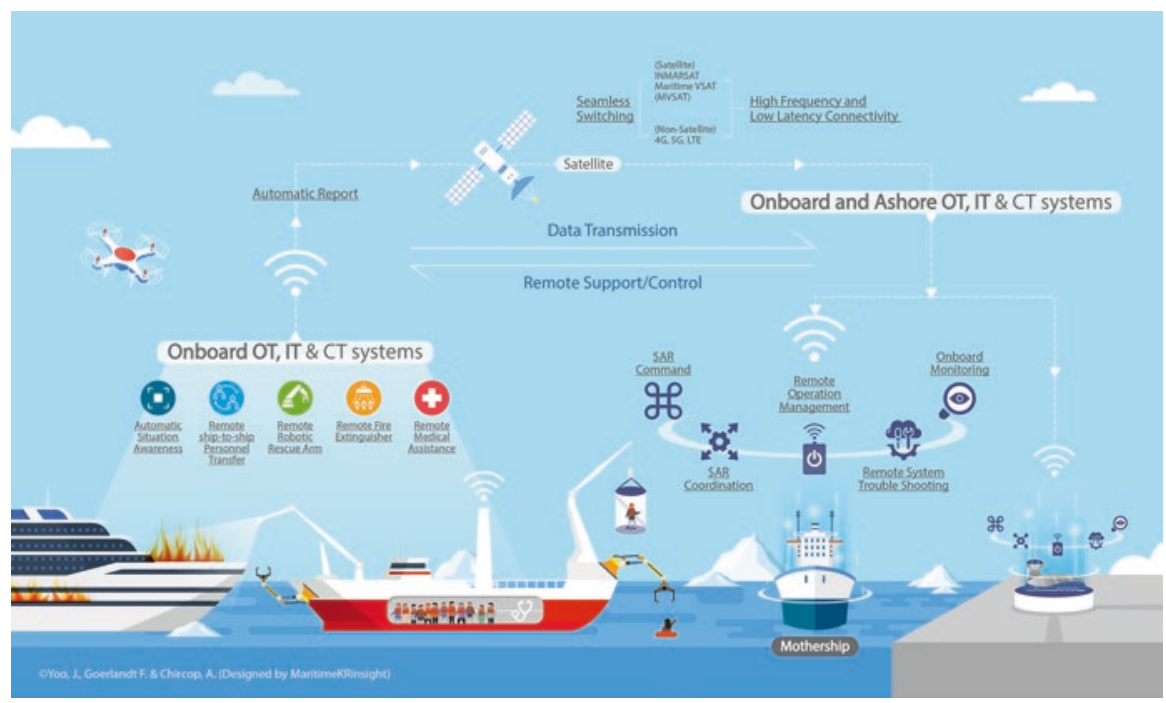

Fig. 5.2 Preliminary system concepts of RO-SARS (the authors' original concepts)

opened the Marine Communication and Traffic Services Centre (MCTS) in Iqaluit, which provided assistance to 112 public and private vessels in the Northern Canada Vessel Traffic Services Zone (NORDREG) between 15 May and 31 July 2019 (Canadian Coast Guard 2019).

\subsubsection{Remote Control Technology and Unmanned RO-SARS}

Among enabling communication technologies, drones are surfacing as an effective tool to search in the Canadian Arctic, saving a significant share of the CAD 14,000 per hour needed for the operation of C130 Hercules aircraft. Drones may be equipped with thermal imaging devices, audio transmitter/receivers and emergency supplies payloads and are capable of streaming real-time images to a control centre (Ward 2019). In addition, unmanned RO-SARS could be a game changer in rescue operations, being equipped with a remote ship-to-ship personnel transfer crane, a robotic rescue arm to save people from the water, a remote fire extinguisher and a remote medical assistance service system.

On the deployment of RO-SARS in northern communities, JRCCs, and other stations, safety risks to SAR personnel would be eliminated; the response time would be accelerated; and cost-efficiency compared with icebreakers, aircraft and helicopters would be enhanced. Furthermore, a complementary solution would be provided to the otherwise insufficient SAR infrastructure, a lack of trained personnel, many uncharted areas and ageing equipment. 


\subsection{Risk Dimensions of RO-SARS in the Canadian Arctic}

\subsubsection{Pre-assessment of Risks}

Given that technology is strongly associated with risk, it should be noted that a technology-led society could turn into a risk-susceptible society (United Nations 2017). Technology-driven risks could increase when organized irresponsibility begins to take advantage of unclear boundaries between ethics, law and technology (Beck 1999; FTI Consulting 2018). Modern risk society features the paradoxical coexistence of economic progress and increased risk, as well as unintended consequences and hidden risks between systems (Jarvis 2007; Renn et al. 2011). Accordingly, more attention should be paid to neighbouring risk components and an adaptive and integrative risk governance combining top-down and bottom-up approaches (Renn et al. 2011). In the maritime domain, risk is commonly defined as the probability of a defined hazard and the severity of its consequences (IMO 2018b). However, risk has been getting more complicated and uncertain in the maritime sector due to increasingly interconnected sociotechnical issues and related governance concerns. As such, the importance of explicitly and systematically considering uncertainties in the risk characterization has been stressed in recent years (Goerlandt and Reniers 2018).

As there are no unmanned RO-SARS in service in the Canadian Arctic at this time, the probability and severity of accidents are unknown. However, the expected minimum functional components could allow the pre-assessment of risks by exploring risk dimensions that could function as problem-framing, early warning and risk screening under the IRGC risk framework (Renn et al. 2011). This pre-assessment is based upon pre-existing maritime regulatory regimes, sociotechnical systems of ships and seafarers, the present stage of remote technology and the status of Canada's SAR response. The functional heterogeneity of unmanned RO-SARS shown in Fig. 5.2 will likely define the nature of risks as systemic under the IRGC risk framework, meaning a risk of a high degree of complexity and uncertainty (Renn et al. 2011).

\subsubsection{Five Risk Dimensions to and from RO-SARS}

\subsubsection{Legality as a Threshold Issue}

A potential concern with the deployment of RO-SARS vessels is their legal status. Canadian maritime law takes a broad definition of a ship in terms of navigability and a shipowner's intent to use it as a ship (CSA 2001, s 2; Thibeault v. Canada 2015 FC 162). Unmanned and remotely operated submersibles have been considered as ships by Canadian courts (Cyber Sea Technologies Inc v. Underwater Harvester Remotely Operated Vehicle 2002 FCT 794). As such, it will not be 
difficult to have unmanned RO-SARS recognized as ships under Canadian maritime law with the usual consequences for safety, security, environment protection, insurability and liability. IMO has also defined MASS as a ship (IMO 2018b), and this characterization can thus be extended to unmanned RO-SARS. Again, the consequence of this definition is to bring MASS within the regulatory domains of international maritime safety, pollution prevention and security standards.

A further concern is whether the absence of a crew on board a SAR vessel might raise an issue of legality under the international law of the sea and international maritime law. The literature has explored possible solutions (Chircop 2017; Yoo and Shan 2019; IMO 2018c; Karlis 2018), which include amending regulatory provisions requiring seafarer presence on board, resorting to constructive treaty interpretation under the Vienna Convention on the Law of Treaties (VCLT 1969, art 61) or introducing new technology exemptions or equivalency under the International Convention for the Safety of Life at Sea (SOLAS) Convention (SOLAS 1974, regs $\mathrm{I} / 4$ (b) and I/5). The effect of these solutions is to extend, to the extent appropriate, the full range of international rules and standards to MASS.

\subsubsection{The Human Element in Seaworthiness}

As in the case of all other ships, SAR vessels are required to be seaworthy. Pursuant to the definition of seaworthiness under the Canadian maritime law (Laing v. Boreal Pacific 2000 CanLII 16,313), RO-SARS as a ship should be reasonably fit in all respects, including SAR operations, to encounter the ordinary perils of the Canadian Arctic. "All respects" can be rephrased as the human and technical aspect of seaworthiness, which is a central principle in maritime law, to ensure the safety of ships under Article 94 of the United Nations Convention on the Law of the Sea (UNCLOS 1982).

The human element in seaworthiness emphasizes the role of a master and crew (SOLAS 1974, regs V/34-1; CSA 2001, s 109(1); Marine Personnel Regulations, s 215, 216). In particular, the International Convention on Standards of Training, Certification and Watchkeeping for Seafarers (STCW 1978, Annex, chaps II and III) sets mandatory minimum qualification standards for masters, officers and watch personnel. With respect to RO-SARS, the assets deployed will not be crewed but will be operated by an onshore team or operators on board motherships. SAR remote controllers will be required to exercise command skills and make tough decisions in a SAR value chain (Aase and Jabour 2015), but without having the benefit of at-sea situational awareness. Because irreparable consequences could occur by any failure of remote controllers on a real-time basis to understand, direct and cooperate with people and ships in distress and other SAR units, it is imperative that remote controllers are appropriately qualified according to generally accepted training standards (Schmied et al. 2017). Among other things, remote controllers will have to be familiar with Volume III of the International Aeronautical and Maritime Search and Rescue Manual, 2000, as amended (IMO 2019). Moreover, remote controllers 
should be conversant with the rules of the road and ice navigation because $70 \%$ of navigational negligence worldwide is attributable to the violation of the rules of steering and sailing (Maritime News 2019). Indeed, remote technology and the human element are inseparable (Rothblum 2000), and it will be necessary to establish uniform standards for SAR remote controllers and simulator-based remote SAR training programs.

\subsubsection{The Technical Element of Seaworthiness}

Seaworthiness of unmanned RO-SARS should be verified for reliability of interconnectivity and interoperability between operation technology (OT) (e.g., sensors and software of situation awareness), information technology (IT) (e.g., data collection, storage and analysis) and communication technology (CT) (e.g., satellite and terrestrial communication systems) in Canadian Arctic operations. Any failure of these technical components of RO-SARS could cause serious and unanticipated hazards to the safety of the SAR operation. In addition to hull structure, engines, machinery, electrical systems and conventional ship equipment, special attention will need to be paid to remote technical elements, including sensor technology, communication links, cyber safety and cybersecurity, and the interface between RO-SARS and remote controllers. Each of these four elements is discussed immediately below. More significantly, practical rescue functionality should be added to the conceptual design of RO-SARS. After all, human and technical elements of RO-SARS will have to prove that their reliability is as capable as the ordinary practice of conventional maritime rescue responders in the Arctic (c.f., Yoo et al. 2019).

A sensor is a device that responds to biological, chemical or physical stimulus such as heat, light, sound and pressure, providing a measured response of the observed stimulus (ISO 2011). Sensor function is critical for situation awareness in a SAR operation. It is enabled by the collection and integration of information from on-board sensors (e.g., heat, sonar and sound detection sensors), cameras and the automatic identification system (AIS) through satellites (Perera and Murray 2019). Even the lookout requirement under the International Regulations for Preventing Collisions at Sea (COLREG) (COLREG 1972, rule 5) is expected to be fulfilled by sensor technology (Lloyd's Register 2017 Code, chap 4, s 4.1.5; Bruhn et al. 2014). However, the quality of data collected through sensors could be compromised by fog, rain, temperature, wind, freezing or harsh weather, which makes the resilience of sensor functions important when breakdowns occur (Bruhn et al. 2014; Lim 2019). As such, a system with a fail-safe design or sensor fusion has been suggested (Kim 2017).

The very recent development of communications technology and government efforts to improve coverage are enablers for unmanned RO-SARS in Canada's Arctic. Even if sensor technology functions well, the data created from the sensors must be seamlessly transmitted to remote controllers as pictured in Fig. 5.2. For this to function effectively, RO-SARS will likely rely on a combination of multitier and 
hybrid satellites and terrestrial communications for ship-to-ship and ship-to-ashore data exchange (Aase and Jabour 2015). This combination will allow remote controllers to perform remote SAR operations (Fig. 5.2).

In 2017 the ransomware called "NotPetya" attacked the Maersk shipping line's central computer system, halting operations at 76 port terminals and costing the shipowner about USD 300 million (Thomson 2017). Cyber incidents can be defined as an occurrence that results in adverse consequences to the entire OT, IT and CT of a ship and its related systems. For example, a virus could corrupt chart data held in an electronic chart display and information system (i.e., cybersecurity), and software controlling engines may malfunction due to a lack of compatibility with upgraded software (i.e., cyber safety) (Jorgensen 2018). Vulnerability may exist in virtual reality bridges, remote control centres and other communication systems. Accordingly, there needs to be stringent testing and certification of system safety and security, access control, security control, penetration testing and adoption of best practices for the protection of OT, IT and CT systems (Woo and Kim 2018; Bureau Veritas 2017, s 1, ss 2.6.2). In addition, a system of attack-safety will be necessary (Kim 2017). Recently, the IMO amended the requirements for an approved safety management system under the International Safety Management (ISM) Code (IMO 1993) to take into account cyber risk management (IMO 2017).

The work scope of SAR remote controllers will not be simple but will be comprehensive so as to include controlling, navigating, monitoring, searching and rescuing. These multifarious functions will require an ergonomic design of the physical and psychological work environment in remote control centres ashore or in motherships. Most importantly, a ship safety management system for RO-SARS and personnel ashore should be put in place as enjoined under the ISM Code (SOLAS 1974, chap 9), because there should be a strong link between the hazards of the actual operations of RO-SARS and the specific design of the safety management system (Valdez Banda et al. 2019).

\subsubsection{Interaction with Ships in Distress and Other SAR Units}

One probable concern of the stakeholders would be the interaction among remote controllers, ships in distress and other SAR units. First, to increase communication links, remote controllers and remote control centres could be stationed in motherships, northern communities or JRCCs (Fig. 5.2). Second, the operation of RO-SARS should be coordinated on-scene to ensure the most effective results with other SAR units engaged (SAR Convention 1979, Annex, chap 4, art 4.7). Third, to maximize the SAR performance and minimize communication error, remote controllers should be better trained and an experienced SAR personnel. Finally, for safer interplay with ships in distress and other SAR units, adaptive dynamic positioning (Witkowska and Śmierzchalski 2018), safe routeing systems (Lehtola et al. 2019), collision avoidance systems (Ozturk and Cicek 2019) and cooperative control algorithms (Almeida et al. 2010) are expected to be useful to RO-SARS. 


\subsubsection{Effective Design of RO-SARS}

Finally, it is the design of unmanned RO-SARS that enables the rescue of people from waves, freezing temperatures and floating ice. At the design stage, depending on the nature of the voyages, the preliminary length of $24 \mathrm{~m}$ or more may entail meeting the requirements of the International Convention on Load Lines (ICLL 1966, Annex A, art 5). Further, having the capacity to carry more than 12 passengers will require RO-SARS of 15 tonnage or less to hold a "passenger vessel safety certificate" issued under the Vessel Certificates Regulations (2007, ss 3, 9, 10). As SOLAS defines a passenger ship to be a vessel carrying more than 12 passengers (SOLAS 1974, regs I/2 and II-1/1), the design of RO-SARS for an international voyage will have to factor in the requirements of SOLAS. Most importantly, an effective feasibility study on design should be made with respect to a ship-to-ship personnel transfer cranes, a robotic rescue arm to deliver people out of water, remote fire extinguishers and remote medical assistance. The authors of this chapter presume that unmanned RO-SARS could contribute to SAR response more likely with respect to rescue operations in coordination with other search equipment such as drones, satellites and aircraft. A further risk assessment of the conceptual design of RO-SARS should be made considering rescue-focused functionality, proper power systems for fast navigation comparable to a high-speed craft, energy sources available in the northern communities, the proper size and length of the asset for delivery of more than 12 persons, a reversionary mode of partly autonomous operation in communication dead zones and structural strength resistant to floating ice and heavy winds (Lee 2018).

\subsubsection{Summary}

Given the five risk dimensions of RO-SARS, most aspects of risk dimensions, except the risk of legality, are contingent upon sociotechnical developments and technical decisions. This complexity and uncertainty makes it difficult to characterize the risk of RO-SARS as being tolerable or not under the IRGC risk framework. Regardless, this problem-framing could at least serve as an early warning and as a basis for specifying design requirements. Moreover, the advantages of RO-SARS, especially in actual rescue operations, will not be easily outweighed by these risk dimensions. Adaptive designs of unmanned RO-SARS and standardization of operation will likely serve as an innovative solution to lagging SAR response time.

\subsection{Governance Implications}

Given the complexity and uncertainty of unmanned RO-SARS in the Canadian Arctic context, this risk-reducing SAR response mechanism necessitates close collaboration between multilevel governance systems ranging from international regulatory bodies 
to national institutions, to Indigenous peoples and to private volunteers (Renn et al. 2011). The human and technical risks of RO-SARS in Canadian Arctic waters will be controlled and managed by international and domestic regulatory regimes and include the engagement of Indigenous rights-holders and public and private stakeholders. In the near future, concern assessment and risk communication with rightsholders and stakeholders under the IRGC risk framework will be also needed.

\subsubsection{RO-SAR and International Conventions}

Under Article 98 of UNCLOS, every state is obliged to require ships registered under its flag to render assistance to people and ships in danger, and every coastal state has a duty to promote the provision of infrastructure for adequate SAR services, emphasizing mutual regional arrangements between coastal states and neighbouring states. In the same vein, the SAR Convention also requires rescue coordination centres to be established by states (SAR Convention 1979, Annex, chap 2.3). Moreover, the Agreement on Cooperation on Aeronautical and Maritime Search and Rescue in the Arctic (Arctic SAR Agreement), to which Canada is a party, obligates states parties to implement the most expeditious border crossing procedures and establishes a legally binding duty of cooperation, including mutual SAR cooperation (Arctic Council 2011, arts 8, 9). Cooperation encompasses information exchange including available SAR facilities and lists of available supply infrastructure (Arctic Portal 2011). The Agreement is intended to enhance the crossboundary mobility of SAR assets. Accordingly, the regional development and deployment of RO-SARS could be seen as supporting states parties' duties under UNCLOS, the SAR Convention and the Arctic SAR Agreement.

\subsubsection{Multilayered Regulatory Regimes Applicable to RO-SARS}

Besides the existence of an international SAR regulatory regime to which Canada is a party, RO-SARS deployed in and navigating the Canadian Arctic will also be governed by Canadian maritime law concerning registration, safety, security, environmental protection, insurability, tort and liability as they will likely be defined as a ship under Canadian maritime law. As "naval auxiliaries and other ships owned or operated by" government and "used only on government non-commercial service" are not bound by the safety of navigation regulations under SOLAS (SOLAS 1974, reg V/1), the safe navigation of RO-SARS owned or operated by the Canadian government will be mostly governed by Canadian national law. Moreover, Section 7 of the Canada Shipping Act, 2001, also implies that RO-SARS owned by the government can avoid the Act by resorting to other new regulations and provides that 
RO-SARS owned or operated by the Canadian Forces are outside of its application, as well as SOLAS and the Polar Code, which applies to ships certified under SOLAS. However, it should be noted that even state-owned RO-SARS will be subject to COLREG, which applies to all ships (COLREG 1972, rule 1). On the other hand, privately owned RO-SARS on international voyages carrying more than 12 passengers, which are more than $24 \mathrm{~m}$ in length, are subject to the construction, equipment and inspection requirements of SOLAS, as well as the watertight and stability requirements of ICLL (Canadian Supplement to the SOLAS Convention, s 2.1.1.1; ICLL 1966, Annex A, art 5).

\subsubsection{Political and Social License from the Arctic States and Northern Communities}

SAR operations in the Canadian Arctic have a probability of crossing land borders and maritime boundaries with the United States and Denmark (Greenland). Even if the federal government approves the operation of RO-SARS, other Arctic states might not welcome the novel technology in waters under their sovereignty or jurisdiction for safety and security reasons (Lee et al. 2018). Accordingly, political and social license in and between neighbouring Arctic states, territories, Indigenous peoples and northern communities is important (van der Vegt 2018). Without their support, the deployment of both RO-SARS and remote control centres in the North could face obstacles. Furthermore, for the effective governance of RO-SARS in the Canadian Arctic, the coordination among federal government departments, JRCCs, volunteer groups, northern communities and neighbouring states will be essential to obtaining full support from aeronautical, maritime and ground SAR units.

\subsection{Risk Prevention Measures: Future Research Needs}

Rapidly advancing remote technology for ships is poised to open new chapters for small cargo delivery (Amos 2019), oil spill response (Maritime Logistics 2019) and tugboat operations (Martine 2019), which also suggests new opportunities for SAR response in the Canadian Arctic. However, the following risk prevention measures which require further research and development are suggested because "risks are created and selected by human actors" (Renn et al. 2011).

First, a concept design for RO-SARS needs to be defined in terms of their size, length, structure, machinery and SAR functionality. Second, a more complete risk characterization should be made with regard to the technical design specification of RO-SARS, one which also accounts for stakeholder concerns and risk perceptions. Third, the Canadian government should develop uniform standards of qualification, training and certification for search and rescue remote controllers in Arctic waters (SQ-SARC) in the near future. Fourth, a prototype of RO-SARS should be 
repeatedly tested, inspected and surveyed through sea trials to verify their human and technical seaworthiness and effective interaction with ships in distress, other SAR units and relevant technologies, including drones. Fifth, remote controllers should be qualified, trained and licensed seafarers for SAR operation under new legal standards that would need to be developed, possibly by the IMO as well as under Canadian federal law. Sixth, stakeholders should increase multitier satellite and terrestrial supports and data transmitters so that the interconnectivity of OT, IT and CT can meet the ordinary practices of SAR responders in the Canadian Arctic. Seventh, a safety management system specifically for unmanned RO-SARS should be put in place with approved training simulators and mandatory procedures (Dasgupta 2017). Eighth, the contribution of northern communities to the practical operation of remote controllers and remote control centres is a key to the success in SAR response in the region (Ward 2019). As such, including these communities in the conception, planning and design of the centres, as well as the associated operating procedures, is highly recommended. Finally, knowledge-sharing and promotion of best practices of RO-SARS ought to be taken up by the Arctic Council through the Protection of the Arctic Marine Environment Working Group, perhaps through its Arctic Shipping Best Practice Information Forum, or the Emergency Prevention, Preparedness and Response Working Group or in collaboration with both Working Groups (Dalaklis 2019).

\subsection{Conclusion}

Given the Canadian Arctic context, unmanned and remotely controlled ships could considerably enhance and complement Canadian SAR capabilities, particularly rescue operations, by reducing response time, infrastructural costs and life risks to responders. However, there are complex and uncertain risks that can be identified under the IRGC risk framework: the qualification and certification of remote controllers, the technical reliability of sensor technology, the stability of communication links, the hazards arising from the breach of cyber safety and cybersecurity, the probable interface errors between RO-SARS and remote controllers and the new design requirements for remote rescue functions such as the remotely operated shipto-ship personnel transfer crane. These risks should be addressed under multilevel governance systems comprising international and national and public and private stakeholders. Most significantly, it is clear that unmanned RO-SARS are in line with the international conventions concerning SAR operations, that there are multilayered regulatory regimes applicable to these novel ships and that these vessels and craft should gain political and social license from the Arctic states and northern communities.

Nonetheless, the risks of deploying unmanned RO-SARS in the region should not be treated as simple. These risks feature a combination of intrinsic heterogeneities such as remote technology, the SAR operation itself and the extreme environment, all of which are complex and uncertain in nature under the terms of the IRGC 
risk framework. Indeed, although the opportunities for RO-SARS look promising, the required technical reliability and actual SAR practicability are unproven in the Arctic context. Hence, it is premature to characterize overall risks as intolerable, tolerable or acceptable. However, the minimal exploration of the risk dimensions taken in the foregoing discussion might trigger feasibility studies and dedicated ship design approaches accounting for the different hazards originating from this novel technology concept, for which new design approaches for unmanned vessels could be applied.

\section{References}

Aase, J. G., \& Jabour, J. (2015). Can monitoring maritime activities in the European high Arctic by satellite-based automatic identification system enhance polar search and rescue? The Polar Journal, 5(2), 386-402.

Allianz. (2018). Safety and shipping review 2018. https://www.agcs.allianz.com/news-andinsights/news/safety-shipping-review-2018.html. Accessed 29 Aug 2019.

Almeida, J., Silvestre, C., \& Pascoal, A. (2010). Cooperative control of multiple surface vessels in the presence of ocean currents and parametric model uncertainty. International Journal of Robust and Nonlinear Control, 20, 1549-1565.

Amos, J. (2019). Autonomous boat makes oyster run. BBC News, May 9. https://www.bbc.com/ news/science-environment-48216966. Accessed 29 Aug 2019.

Arctic Council. (2009). Arctic marine shipping assessment 2009 report. Troms $\varnothing$ : Arctic Council.

Arctic Council. (2011). Agreement on Cooperation on Aeronautical and Maritime Search and Rescue in the Arctic (12 May 2011, entered into force in 2013).

Arctic Portal. (2011). Arctic search and rescue agreement. Arctic Portal, 23 May. https://arcticportal.org/ap-library/yar-features/421-arctic-search-and-rescue-agreement. Accessed 29 Aug 2019.

Aven, T., \& Renn, O. (2010). Risk management and governance. Heidelberg: Springer.

Baraniuk, C. (2017). The ships that could change the seas forever. BBC, 19 September. http:// www.bbc.com/future/story/20170918-the-ships-that-could-change-the-seas-forever. Accessed 29 Aug 2019.

Beck, U. (1999). World risk society. Cambridge: Polity Press.

Boucher, M. (2019). Acquisition of three satellites and polar radars. Space Q, February 6. http:// www.spaceq.ca/canadian-arctic-security-increasing-with-acquisition-of-three-satellites-andpolar-radars/. Accessed 29 Aug 2019.

Brown, B. (2018). Arctic SAR efforts need better training, more Inuktut. Nunatsiaq News, 5 December. https://nunatsiaq.com/stories/article/arctic-sar-efforts-need-better-training-moreinuktut-senate-report-says/. Accessed 29 Aug 2019.

Bruhn, W. C., Burmeister, H., Long, M. T., \& Moræus, J. A.. (2014). Conducting look-out on an unmanned vessel: Introduction to the advanced sensor module for MUNIN's autonomous dry bulk carrier. In Proceedings of the International Symposium Information on Ships (ISIS 2014), Hamburg, Germany, 4-5 September.

Bureau Veritas. (2017). NI641 guidelines for autonomous shipping. https://marine-offshore. bureauveritas.com/ni641-guidelines-autonomous-shipping. Accessed 29 Aug 2019.

Canadian Coast Guard (CCG). (2018, April 27). Maritime search and rescue (SAR) in Canada. http://www.ccg-gcc.gc.ca/eng/CCG/SAR_Maritime_Sar\#Maritime_SAR. Accessed 29 Aug 2019. 
CCG. (2019). Canadian Coast Guard 2019Arctic operations nearing mid-season. News Release, 30 August. https://www.canada.ca/en/canadian-coast-guard/news/2019/08/canadian-coast-guard2019-arctic-operations-nearing-mid-season.html. Accessed 15 Sept 2019.

Chase, S. (2013). Coast guard commander, pilot and Arctic scientist die in helicopter crash. The Globe and Mail, 10 September. https://www.theglobeandmail.com/news/national/three-die-incanadian-coast-guard-helicopter-crash-in-northwest-territories/article14216223/. Accessed 29 Aug 2019.

Chircop, A. (2017). Testing international legal regimes: The advent of automated commercial vessels. German Yearbook of International Law, 60, 109-142.

Chircop, A., Pamel, P., \& Czarski, M. (2018). Canada's implementation of the polar code. Journal of International Maritime Law, 24, 428-450.

Cho, S. 2019. 세계 초소형위성 활용현황과 해양신산업 연계방안 [The world's utilization of nano satellites and how to link new marine industry]. Presented at the Conference of Maritime Cluster Networking, Korea, August 2019.

COLREG. (1972). International Regulations for Preventing Collisions at Sea, 1972, 1050 UNTS 16.

Crown-Indigenous Relations and Northern Affairs Canada. (2019). Toward a new Arctic policy framework. https://www.rcaanc-cirnac.gc.ca/eng/1499951681722/1537884604444. Accessed 29 Aug 2019.

CSA. (2001). Canada Shipping Act, 2001, SC 2001, c 26.

Cyber Sea Technologies Inc v. Underwater Harvester Remotely Operated Vehicle, 2002 FCT 794.

Dalaklis, D. 2019. Arctic SAR: Current infrastructure and opportunities for maritime autonomous surface ships (MASS). Presented at the Maritime Search and Rescue 2019 Conference, Tallinn, Estonia, 14-16 May. https://doi.org/10.13140/RG.2.2.18463.00167.

Dasgupta, S. (2017). Risk assessment for ships: A general overview. Marine Insight, 2 August. https://www.marineinsight.com/marine-safety/risk-assessment-for-ships-a-general-overview/. Accessed 29 Aug 2019.

Esri. (n.d.). The Canadian Arctic and the Northwest Passage. https://www.arcgis.com/apps/ MapJournal/index.html?appid=3920f55772dd4aa8aa35dd4b219f032e \&webmap=bef6b47a5 0b44ed99e4bf6644b77a279. Accessed 29 Aug 2019.

Fisheries and Oceans Canada. (2009). Archived - Government of Canada response to the Report of the Standing Senate Committee on Fisheries and Oceans: Rising to the Arctic Challenge: Report on the Canadian Coast Guard. https://www.dfo-mpo.gc.ca/reports-rapports/200910aeng.htm. Accessed 29 Aug 2019.

FTI Consulting Inc. (2018). Artificial intelligence: The race is on the global policy response to AI. https://euagenda.eu/upload/publications/untitled-128126-ea.pdf. Accessed 29 Aug 2019.

Goerlandt, F., \& Reniers, G. (2018). Prediction in a risk analysis context: Implications for selecting a risk perspective in practical applications. Safety Science, 101, 344-351.

Government of Canada. (2009). Canada's Northern Strategy. http://www.northernstrategy.gc.ca/ index-eng.asp. Accessed 8 Aug 2019.

Government of Canada. (2010). Statement on Canada's Arctic foreign policy: Exercising sovereignty and promoting Canada's Northern Strategy abroad. https://www.international.gc.ca/ world-monde/international_relations-relations_internationales/arctic-arctique/arctic_policycanada-politique_arctique.aspx?lang=eng. Accessed 29 Aug 2019.

Haddou-Riffi, R. 2018. Dramatic drone rescue of 2 Australian swimmers billed as a first. $a b c$ NEWS, 19 January. https://abcnews.go.com/International/drone-rescue-australian-swimmersbilled/story?id=52429138. Accessed 29 Aug 2019.

ICLL. (1966). International Convention on Load Lines, 1966, 640 UNTS 133, as amended.

IMO (International Maritime Organization). (1993). International Management Code for the Safe Operation of Ships and for Pollution Prevention (International Safety Management (ISM) Code), IMO Doc. A/18/Res.741 (17 November) (entered into force 1 July 1998), as amended.

IMO. (2017). Maritime cyber risk management in safety management systems, IMO Resolution MSC. 428(98) (16 June).

IMO. (2018a). Regulatory scoping exercise for the use of maritime autonomous surface ships (MASS): Report of the Working Group, Annex 1: Framework for the regulatory scoping exercise, IMO Doc. MSC 99/WP.9 (23 May). 
IMO. (2018b). Revised guidelines for formal safety assessment (FSA) for use in the IMO rulemaking process, IMO Doc. MSC-MEPC.2/Circ.12/Rev.2 (9 April).

IMO. (2018c). Regulatory scoping exercise for the use of maritime autonomous surface ships (MASS): Final report: Analysis of regulatory barriers to the use of autonomous ships submitted by Denmark, IMO Doc. MSC 99/INF.3. (18 January).

IMO. (2019). IAMSAR manual. http://www.imo.org/en/OurWork/Safety/ RadioCommunicationsAndSearchAndRescue/SearchAndRescue/Pages/IAMSARManual. aspx. Accessed 29 Aug 2019.

ISO (International Organization for Standardization). (2011). ISO/IEC/IEEE 21451-7:2011: Information technology - Smart transducer interface for sensors and actuators - Part 7: Transducer to radio frequency identification (RFID) systems communication protocols and transducer electronic data sheets (TEDS) formats. https://www.iso.org/obp/ui/fr/\#iso:std:isoiec-ieee:21451:-7:ed-1:v1:en:fn:1. Accessed 29 Aug 2019.

Jarvis, D. S. L. (2007). Risk, globalisation and the state: A critical appraisal of Ulrich Beck and the world risk society thesis. Global Society, 21(1), 23-46.

Jorgensen, R. N. (2018). Industry publishes improved cyber guidelines. BIMCO. https://www. bimco.org/news/priority-news/20181207-industry-publishes-improved-cyber-guidelines. Accessed 29 Aug 2019.

Karlis, T. (2018). Maritime law issues related to the operation of unmanned autonomous cargo ships. WMU Journal of Maritime Affairs, 17, 119-128.

Kim, Y. (2017). 자율주행차량 센서 취약성 분석의 필요성 [Security of sensors for self-driving cars]. Presented at KRnet 2017, the 25th Korea internet conference for digital transformation toward intelligent information society, Seoul, Korea, 26 June. http://www.krnet.or.kr/board/ data/dprogram/2172/D1-3_\%B1\%E8\%BF\%EB\%B4\%EB.pdf. Accessed 29 Aug 2019.

Laing v. Boreal Pacific, 2000 CanLII 16313.

Lasserre, F. (2018). Arctic shipping: A contrasted expansion of a largely destinational market. In M. Finger \& L. Heininen (Eds.), The global Arctic handbook (pp. 83-100). Singapore: Springer Nature.

LeBlanc, P. (2018a). Canada's northern people deserve better Arctic SAR capabilities. The Maritime Executive, 10 March. https://www.maritime-executive.com/editorials/canada-snorthern-people-deserve-better-arctic-sar-capabilities. Accessed 29 August 2019.

LeBlanc, P. (2018b). Is the Canadian Arctic more secure now? The Maritime Executive, 30 October. https://www.maritime-executive.com/editorials/is-the-canadian-arctic-more-securenow. Accessed 29 Aug 2019.

Lee, K. (2018). 자율운항선박을 위한 원격제어관리시스템 [Remote control management system for autonomous ships]. Journal of the Korea Convergence Society, 9(11), 45-51.

Lee, S., Choi, J., \& Yoo, J. (2018). 유엔해양법협약상 국가관할권에 따른 자율운항선박의 규 범적 쟁점사항 [Normative issues of maritime autonomous surface ships (MASS) pursuant to the state jurisdictions under UNCLOS]. KMI Ocean Policy Research, 33(2), 145-180.

Lehtola, V., Montewka, J., Goerlandt, F., Guinness, R., \& Lensu, M. (2019). Finding safe and efficient shipping routes in ice-covered waters: A framework and a model. Cold Regions Science and Technology, 165, 1-14.

Lim, Y. (2019). SW기업의 새로운 기회의 창, 자율운항선박 [A new window of opportunities for SW companies: Autonomous vessels]. Software Policy \& Research Institute Insight Report 2018-005, 30 January. https://spri.kr/posts/view/22562?code=insight.

Lloyd's Register. (2017). Unmanned Marine Systems Code. https://www.lr.org/en/unmannedcode/. Accessed 29 Aug 2019.

Marine Personnel Regulations, SOR/2007-115 (Canada).

Maritime Logistics. (2019). Sea machines demonstrates autonomous spill-response vessel. Maritime Logistics Professional, 21 August. https://www.maritimeprofessional.com/news/ machines-demonstrates-autonomous-spill-response-349756. Accessed 29 Aug 2019.

Maritime News. (2019). 기초항법 위반하고 운항하면 최대 1000 만원 과태료 부과 [Up to 10 million won penalty for the navigation in violation of the basic rules of steering and 
sailing]. The Korea Maritime News, 18 June. http://www.haesanews.com/news/articleView. html?idxno=85508. Accessed 29 Aug 2019.

Martine, E. (2019). How tugs are leading the way in automation and remote control. Riviera, 25 July. https://www.rivieramm.com/news-content-hub/news-content-hub/how-tugs-are-leadingthe-way-in-automation-and-remote-control-55676. Accessed 29 Aug 2019.

National Defence. (2019). Enhanced satellite communication project - Polar. Government of Canada, 1 August. http://dgpaapp.forces.gc.ca/en/defence-capabilities-blueprint/projectdetails.asp?id=1279. Accessed 29 Aug 2019.

Nuvitik Communications. (2018). Subsea fibre investment for Inuit communities in Nunavik. 7 September. http://nuvitik.ca/2018/09/07/14-nunavik-inuit-communities-to-benefit-fromsubsea-fibre/. Accessed 29 Aug 2019.

Office of the Auditor General of Canada. (2013). 2013 Spring report of the Auditor General of Canada: Chapter 7-Federal search and rescue activities. http://www.oag-bvg.gc.ca/internet/ English/parl_oag_201304_07_e_38192.html. Accessed 29 Aug 2019.

Office of the Auditor General of Canada. (2014). 2014 Fall report of the Commissioner of the Environment and Sustainable Development: Chapter 3-Marine navigation in the Canadian Arctic. http://www.oag-bvg.gc.ca/internet/English/parl_cesd_201410_03_e_39850.html. Accessed 29 Aug 2019.

Ozturk, U., \& Cicek, K. (2019). Individual collision risk assessment in ship navigation: A systematic literature review. Ocean Engineering, 180, 130-143.

Perera, L. P., \& Murray, B. (2019). Situation awareness of autonomous ship navigation in a mixed environment under advanced ship predictor. Presented at the 38th International Conference on Ocean, Offshore and Arctic Engineering, Glasgow, Scotland, 9-14 June.

Plass, S., Clazzer, F., \& Bekkadal, F.. (2015). Current situation and future innovations in Arctic communications. In IEEE 82nd Vehicular Technology Conference, Boston, MA, USA, 6-9 September 2015 (VTC2015-Fall). https://doi.org/10.1109/VTCFall.2015.7390883.

Renn, O., Klinke, A., \& van Asselt, M. (2011). Coping with complexity, uncertainty and ambiguity in risk governance: A synthesis. Ambio, 40(2), 231-246.

Rothblum, A. M. (2000). Human error and marine safety. Bowles-Langley Technology. http:// bowles-langley.com/wp-content/files_mf/humanerrorandmarinesafety26.pdf. Accessed 29 Aug 2019.

SAR Convention. (1979). International Convention on Maritime Search and Rescue, 1979, 1405 UNTS 118, as amended.

Schmied, J., et al. (2017). Chapter 25: Maritime operations and emergency preparedness in the Arctic: Competence standards for search and rescue operations contingencies in polar waters. In K. Latola \& H. Savela (Eds.), The interconnected Arctic - UArctic congress 2016 (pp. 245-255). Cham: Springer.

Senate of Canada. (2018). When every minute counts: Maritime search and rescue. Report of the Standing Committee on Fisheries and Oceans. Ottawa, Senate of Canada.

SOLAS. (1974). International Convention for the Safety of Life at Sea, 1974, 1184 UNTS 2, as amended.

STCW. (1978). International Convention on Standards of Training, Certification and Watchkeeping for Seafarers, 1978, 1361 UNTS 2, as amended.

Struzik, E. (2018). In the melting Arctic, a harrowing account from a stranded ship. YaleEnvironment360, 29 August. https://e360.yale.edu/features/in-the-melting-arctic-harrowing-account-from-a-stranded-ship. Accessed 29 Aug 2019.

Thibeault v. Canada, 2015 FC 162.

Thomson, I. (2017). NotPetya ransomware attack cost us $\$ 300 m$ - Shipping giant Maersk. The Register, 16 August. https://www.theregister.co.uk/2017/08/16/notpetya_ransomware_attack_ cost_us_300m_says_shipping_giant_maersk/. Accessed 29 Aug 2019.

Transport Canada. (2018). Drones in the Canadian Arctic. https://www.tc.gc.ca/en/programs-policies/programs/national-aerial-surveillance-program/drones-canadian-arctic.html. Accessed 29 Aug 2019. 
TSBC (Transportation Safety Board of Canada). (2012). Grounding: Passenger Vessel Clipper Adventurer, Coronation Gulf, Nunavut, 27 August 2010. Marine Investigation Report M10H0006. Ottawa: TSBC.

TSBC. (2019). Grounding of passenger vessel Akademik Ioffe. Marine transportation safety investigation M18C0225. https://www.tsb.gc.ca/eng/enquetes-investigations/marine/2018/ $\mathrm{m} 18 \mathrm{c} 0225 / \mathrm{m} 18 \mathrm{c} 0225 . \mathrm{html} \# 3$. Accessed 21 Nov 2019.

UNCLOS. (1982). United Nations Convention on the Law of the Sea, 1982, 1833 UNTS 3.

United Nations. (2017). With technology rapidly transforming society, countries need delivery models to implement development goals, speakers say as innovation forum concludes. UN Doc. ECOSOC/6833 (16 May). http://www.un.org/press/en/2017/ecosoc6833.doc.htm. Accessed 29 Aug 2019.

University of Toronto. (2019). U of T researchers to design microsatellites for Arctic monitoring. UofT News, 1 February. https://www.utoronto.ca/news/u-t-researchers-design-microsatellitesarctic-monitoring. Accessed 29 Aug 2019.

Valdez Banda, O. A., Kannos, S., Goerlandt, F., van Gelder, P., Bergström, M., \& Kujala, P. (2019). A systemic hazard analysis and management process for the concept design phase of an autonomous vessel. Reliability Engineering and System Safety, 191, 106584.

van der Vegt, R. G. (2018). Risk assessment and risk governance of liquefied natural gas development in Gladstone, Australia. Risk Analysis, 38(9), 1830-1846.

VCLT. (1969). Vienna Convention on the Law of Treaties, 1969, 1155 UNTS 331.

Vessel Certificates Regulations, SOR/2007-31 (Canada).

Ward, G. (2019). Drones: Arctic search and rescue. Watertoday.ca, 2 May. http://www.watertoday. ca/ts-drones-arctic-search-and-rescue.asp. Accessed 29 Aug 2019.

Wärtsilä.(2017).Wärtsiläsuccessfullytestsremotecontrolshipoperating capability. GlobeNewswire, 1 September. http://www.globenewswire.com/news-release/2017/09/01/1106496/0/ en/W\%C3\% A4rtsi1\%C3\% A4-successfully-tests-remote-control-ship-operatingcapability.html. Accessed 29 Aug 2019.

Witkowska, A., \& Śmierzchalski, R. (2018). Adaptive dynamic control allocation for dynamic positioning of marine vessel based on backstepping method and sequential quadratic programming. Ocean Engineering, 163, 570-582.

Woo, J., \& Kim, M.. (2018). Samsung Heavy's cyber security solution for smart ship certified in U.S. Pulse, 26 March. https://pulsenews.co.kr/print.php?year=2018\&no=192727. Accessed 29 Aug 2019.

WorldAtlas. (2018) Where is the Canadian Arctic archipelago? https://www.worldatlas.com/articles/where-is-the-canadian-arctic-archipelago.html. Accessed 29 Aug 2019.

Yoo, J., \& Shan, D.. (2019). Legal status of an onshore remote controller of maritime autonomous surface ships (MASS) under the Canadian maritime law and IMO international conventions. Presented at 2019 Annual Conference of the Canadian Transport Research Forum, Vancouver, Canada, 26-29 May.

Yoo, J., Jung, C., \& Lee, S. (2019). 자율운항선박의 통제원리로서의 선원의 상무와 해사법 규 개정 방안 [A study on the ordinary practice of seamen as a controlling principle of MASS and its revision of maritime law]. Maritime Law Review, 31(2), 55-88. 
Open Access This chapter is licensed under the terms of the Creative Commons Attribution 4.0 International License (http://creativecommons.org/licenses/by/4.0/), which permits use, sharing, adaptation, distribution and reproduction in any medium or format, as long as you give appropriate credit to the original author(s) and the source, provide a link to the Creative Commons license and indicate if changes were made.

The images or other third party material in this chapter are included in the chapter's Creative Commons license, unless indicated otherwise in a credit line to the material. If material is not included in the chapter's Creative Commons license and your intended use is not permitted by statutory regulation or exceeds the permitted use, you will need to obtain permission directly from the copyright holder. 